Historic, archived document

Do not assume content reflects current scientific knowledge, policies, or practices. 



\section{ON PINES}

Two recent tests in central Louisiana, planned in cooperation with the U.S. Fish and Wildlife Service, have shown that several chemicals are effective in reducing cattle browsing of planted slash pines. The most promising are ZAC, a zinc compound; TMTD, a thiram compound; ZIP, a commercial rabbit and deer repellent which contains 30 percent $\mathrm{ZAC}$; and a mixture of copper carbonate and asphalt emulsion.

In a 1957 test, slash pine seedlings were handsprayed in the field immediately following planting. The native blueste $\mathrm{m}$ forage was heavily grazed by cattle from late winter through the summer. Sixty-four percent of the untreated seed lings were severely damaged or killed by midJune. Losses of seedlings treated with copper carbonate, ZAC, or TMTD were only half as great.

In 1958, seedlings were treated with the same repellents plus ZIP. Moreover, three methods of application were tested--spraying in the nursery before lifting, bundle dipping just prior to planting 。 and spraying individual seedlings in the field after planting. Seedlings sprayed with copper carbonate and asphalt emulsion in the nursery and baled for shipping were seriously injured by the chemical. Apparently, close confinement of treated seedlings in the bale several days caused the damage. The other 11 combinations of application methods and chemicals substantially reduced grazing damage. By June, no more than 16 percent of the treated seedlings were damaged, as compared to 30 percent on untreated plots.

The mixture of copper carbonate and asphalt emulsion is relatively cheap and easy to prepare. Seedlings should be treated by dipping tops of bundles shortly before planting. Repellent materials will cost about $\$ 0.20$ per 1,000 seedlings. 
The repellent is formulated by diluting 3 pounds of asphalt emulsion (Flintkote C-13-HPC) in 10 quarts of water and adding 2 pounds of copper carbonate (55 percent copper). The solution should be stirred or agitated frequently to prevent the copper carbonate from settling out. New solutions should be made up every 2 or 3 days.

Formulations containing ZAC and TMTD are difficult to prepare, but ready-mixes are now commercially available.-Don A. Duncan and Louie B. Whitaker.

\section{HARDWOODS RECOVERING FROM DROUGHT}

Observations throughout the Midsouth hardwood region indicate that dieback and mortality result ing directly or indirectly from the $1952-1956$ drought have ended. After the ample and welldistributed rains of 1957 and 1958, very little additional mortality and no new dieback can be seen. Live limbs below dead tops showed renewed vigor in 1958, indicating that the effects of the drought have finally halted.

Rainfall deficit from 1952 through 1956 averaged more than 5 inches per years with most of the shortage during the growing season. The drought began in the summer of 1952, when precipitation was more than 10 inches below normal. Soil moisture was never fully recharged during the 4 succeeding years, so that the deficit of available soil moisture accumulated. Some previous single years of $\mathrm{drought}$ have been worse than any of these 5,but weather records fail to reveal as long a sequence of dry years.

The apparent cessation of damage should allay the anxiety of forest owners as to whether continued management of hardwoods is feasible.W. M. Broadfoot and E.R.Toole. 


\section{2, 4,5-T BETTER IN DIESEL OIL}

In the Ouachita Mountains of Arkansas, 2,4,5-T in a diesel oil carrier, applied with a tree injector, killed the crowns of 98 percent of the treated trees in one year. The same concentration of the chemical with a water carrier gave a 65-percent kil1. The mixture was applied to white oak stems 3 to 6 inches in $d . b . h$. at a dosage of one injection (about $1 / 4$ ounce of mixture). per inch of $d . b . h$. No sprouting occurred with either treatment.

The mixture tested was a 44-pound ahg. (acid per hundred gallons) concentration of $2,4,5-T$ ( 4 lbs acid equivalent of 2 ethyl-hexyl ester of 2,4,5-trichlorophenoxyacetic acid... Edwin R. Lawson.

\section{RECENT PUBLICATIONS}

*Beal, R.H. Life habits and control of pine tip moth: results from preliminary studies. Southern Forest Pest Reporter 24, 5 pp.

*Duffield, J.W. and Snyder, E. B. Benefits from hybridizing American forest tree species. Journal of Forestry, November 1958, pp. 809-815.

*Echols, R.M. The ampliscope--an instrument for wood-fiber measure. ments. Journal of Forestry, January 1959. pp。43-44.

*Grigsby, H. C. Two promising pine hybrids for the Mid-South. Southern Lumberman, January 1, 1959, pp. 32-33.

Hails. L.K. and Ripley, T.H, The future of wildlife in the southern forest. Forest Farmer, December 1958, pp. 5, 14-16.

*Maisenhelder. L. C. Understory plants of bottomland forests. Occasional Paper 165。 40 pp.

*Mitche11, H.L., and Wheeler, P.R. The search for wood quality. In 2 parts. Forest Farmer, January 1959, pp. 4-6; February 1959. pp. 10-12. [Specific gravity as a measure of wood quality in Mississippi.]

* Smith. J. L. Tests of injected chemicals for hardwood control in the Arkansas mountains. 3 pp.

Smith, V.K. Jr。Treating stored wood: decay in pulpwood in. ventories can be reduced. Pulpwood Production. February 1959. pp. 10,12 .

*Toole. E.R. Decay after fire injury to southern bottom-land hardo woods. USDA Technical Bulletin 1189, $25 \mathrm{pp}$.

*Warren, L。O. and Coyne. J.F. The pine sawfly, Neodiprion taedae linearis Ross, in Arkansas.Arkansas Agricultural Experiment Station Bulletin 602, 23 pp.

Wilson, R.C., and Christopher, J.F. There's an adequate supply of wood utility poles. Wood Preserving News, November 1958, pp. 10-12. (Aiso in Telephony, July 26, 1958, pp. 28-30。)

*Woods, F.W. Copel and, O.L. JY.o and Ostrom, C.E. Soil manage. ment for forest trees. Sorl, Yearbook of Agriculture for 1957. pp。 $710-715$ 。

In SOUTHERN LUMBERMAN。 DecembeT 15, 1958 .

*Averyo Gene。 Easy as P.I。! Pp。109-111.

* Ferguson, E.R. Plows for woods planting. Pp.92-93.

*Johnson, R.L. Bluff Hillsooideal for hardwood timber proo duction。Pp.126-128.

*Russell. T.E. Spacingoits pole in the growth of planted slash pine. Pp. 115-117.

*Sinalley。 GoW。 Stand impoventent pays off. Pp.100-102.

* Copies are avalibie at the Southern Station. 